\title{
河道撹乱のためのフラッシュ放流による 旧流路の維持に関する研究 \\ STUDY ON THE MAINTENANCE OF FORMER WATERCOURSES BY THE ARTIFICIAL FLOOD FOR RIVER CHANNEL DISTURBANCE
}

\author{
住友慶三 $1 \cdot$ 渡邊康玄 ${ }^{2} \cdot$ 泉典洋 $^{3} \cdot$ 山口里実 4 ・横濱秀明 5 \\ Keizo SUMITOMO, Yasuharu WATANABE, Norihiro IZUMI, \\ Satomi YAMAGUCHI and Hideaki YOKOHAMA
}

\author{
1正会員 株式会社ドーコン 河川環境部（三004-8585 札幌市厚別区厚別中央1条5丁目4-1） \\ 2正会員 工博 北見工業大学教授 工学部社会環境工学科（广090-8507 北見市公園町165） \\ 3正会員 工博 北海道大学教授 工学研究科（干060-0808 札幌市北区北8条西5丁目） \\ 4正会員 工博 土木研究所 寒地土木研究所（干060-8602 札幌市豊平区平岸1条3-1-34） \\ 5 国土交通省 北海道開発局 帯広開発建設部 治水課（干080-8585 帯広市西4条南8丁目）
}

\begin{abstract}
The effect of the artificial flood to river channel disturbance is clarified quantitatively using the results of field observations and numerical simulations (iRIC Nays2D 4.2). The 1st viewpoint is maintenance of distributary leading to former watercourses which induces river channel disturbance at the time of a large flood. The 2nd viewpoint is a scale of river channel disturbance at the time of a large flood. The difference between the existence and non-existence of the artificial flood has been discussed. It was evaluated quantitatively that artificial flood is effective in maintenance of distributaries. Moreover, it was found quantitatively that the effect of mainstream alternation at bifurcations during a large flood which is expected by the maintenance of distributaries.
\end{abstract}

Key Words : The Satsunai River, artificial flood, distributary, river channel disturbance

\section{1.はじめに}

一級水系十勝川の一次支川である札内川は，かつては 複列流路と広い碩河原が特徴の河川であったが，2006〜 2010年の年最大流量の大幅な減少等が影響し，河道内が 著しく樹林化した1),2).これにより，流路は固定化し，䃇 河原の面積は急速に減少した. 図-1に樹林・礉河原面積 の経年変化を，写真-1に樹林化の様子をそれぞれ示した.

この状況を踏まえ，札内川では，磼河原の再生を目的 として2012年より6月末に札内川ダムから最大放流量 110 $\sim 120 \mathrm{~m}^{3} / \mathrm{s}$ のフラッシュ放流を実施している ${ }^{1), 2)}$. この放 流は，確率規模1/1の出水に相当するが，2012年の放流 では礫河原の再生はほとんど見られなかった22.

一方，山口ら ${ }^{3)}$ は，2011年に発生した確率規模約 $1 / 20$ の出水において，樹林内に旧流路がみられる箇所のうち， 主流路と旧流路の分岐部の河床高が同程度の箇所では大 規模な擋乱が発生し，土砂堆積により旧流路流入部が閉 塞した箇所は擋乱が小規模だったことを確認した.この
ことから，流路固定化の解消には旧流路の維持が重要と の観点で検討を行い，既に閉塞した旧流路を回復するた めには, 淵下流の河床勾配が急になる箇所を選定して旧 流路へ接続掘削することが効率的であることを示した.

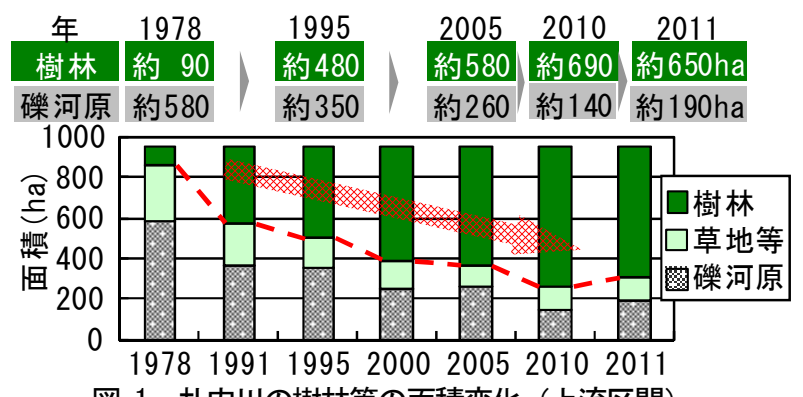

図-1 札内川の樹林等の面積変化（上流区間）

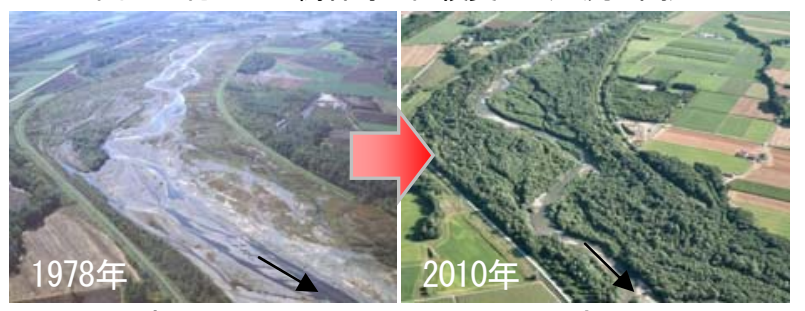

写真-1 札内川の樹林化の状況（上流区間） 
他方，清水ら ${ }^{4), 5}$ は，渡良瀬川の固定化した中州に掘削 路を設け，出水を導いて中州内で洪水擋乱を誘発させる ことにより，樹林化抑制等の効果が得られることを明ら かにしている。

以上のことを踏まえ，今後の他河川への適用を考慮し て, 効率的に旧流路を回復できる箇所の選定方法につい て河道変遷を考慮した考察を加えるとともに，旧流路の 回復に必要な掘削規模及び旧流路の維持により期待され る効果について検討を行った.

本論文は，フラッシュ放流による旧流路の維持，その ことによる碩河原再生への寄与の検証を目的としている.

\section{2. 効率的に旧流路の回復を図る方法}

主流路の固定化には分岐流の消失が大きく影響してい ると考えられる6)ため，2013年及び2014年に実施したフ ラッシュ放流では，直前に旧流路流入部の堆積土砂を平 水位程度で掘削して主流路から旧流路へ分岐接続した工 区を6箇所設けた上で実施された，工区の位置図，工区 設置区間の河道特性，年最大流量及び工区の掘削図を図 -2〜図-4に示す．6工区の掘削条件は同様としたが，D 下流工区だけはフラッシュ放流時の旧流路への分岐流入 が緩やかで，変化は最も小さかった．他の5工区は旧流 路への流入により河床擋乱や植物の倒伏等が確認された.

複列砂州河道では, 河岸侵食を伴って川幅の広い部分

(腹) と狭い部分（節）が流下方向に交互に現れる77. この流路形状に着目し, 旧流路への流入量が多く2014年
8月出水 (確率規模約 $1 / 3$, 暫定值)で流路変動のきっか けとなったE工区と，変化が小さかったD下流工区の流 路平面形の変遷及び河床縦断形を, 既往航空写真及び 2013年計測のレーザープロファイラーデータ（以下， LP）により確認した。 図-5に，それぞれの箇所の流路 変遷と河床維断形を示寸。

図-5の流路平面形の変遷を見ると，節は横断方向の流 路変動が小さく, 腹は節の下流側に位置し，大きく流路 変動している. 流路変遷から読み取ることができる節と 腹を瀬・淵で分類すると，節は河床勾配が水平に近い淵， 腹は淵下流の勾配1/110程度の瀬にあたる. 他の4工区も 同様に節と淵，腹と瀬の対応関係がみられた．図-5の河 床縦断図を見ると，E工区は節の直下流，D下流工区は 節の位置で旧流路に引き込まれていたことが読み取れる。 河床勾配が緩やかな場合は急な場合に比べて分岐流量配 分比が著しく低下寸る3)ため, D下流工区は河床勾配の 影響で旧流路への流入量が少なくなったと考えられる.

効率的に旧流路を回復するためには, 詳細な河床縦断 形を把握し，節の直下流の急勾配部で旧流路へ引き込む ことが重要と考えられる. しかし, 約200mピッチで実 施されている定期横断測量結果のみで縦断的な瀬・淵特 性を把握することは困難であり, 詳細な河床縦断形を把 握するための調查を全川で実施することも容易ではない． そこで, 複列流路を回復しようとする場合は，旧流路の 分布と節・腹の位置を既往航空写真により確認し，節の 上下流区間に着目して詳細な河床縦断形の調査を行い, 旧流路接続掘削の位置を選定することがより効率的と考 えられる。

\begin{tabular}{|c|c|}
\hline $\begin{array}{c}\text { 当該区間の河道特性 } \\
\text { ○河床勾配 : 1/110程度, ○河道幅(堤間)：400 450m程度, } \\
\text { O碟河原幅 : 50 150m程度, ○旧流路河床幅 : } 10 \mathrm{~m} \text { 程度 }\end{array}$ & $\begin{array}{c}\text { 旧流路引き込みの考え方 } \\
\text { B } \cdot \text { D } \cdot \text { E工区 : 湾曲外岸で旧流路引き込み, } \\
\text { \&工区 : 砂州の発達を考慮, \G工区 : 連続する複列流路の回復 }\end{array}$ \\
\hline
\end{tabular}

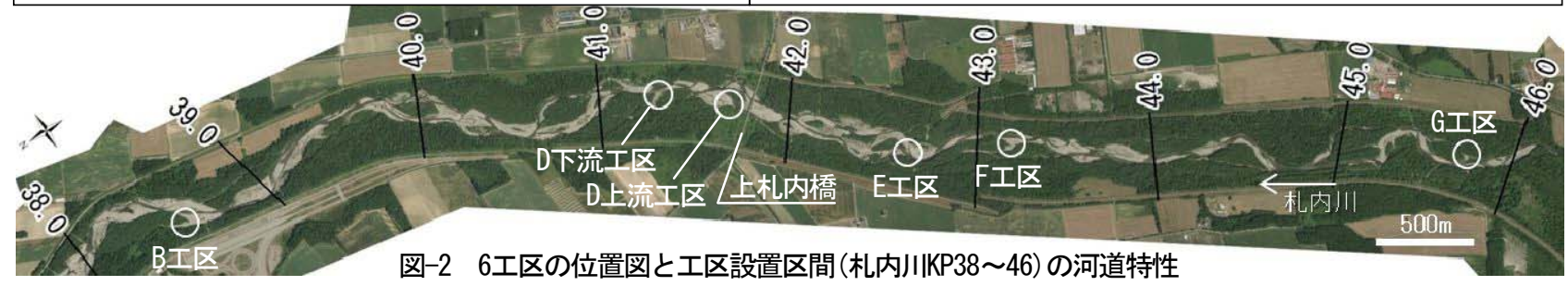

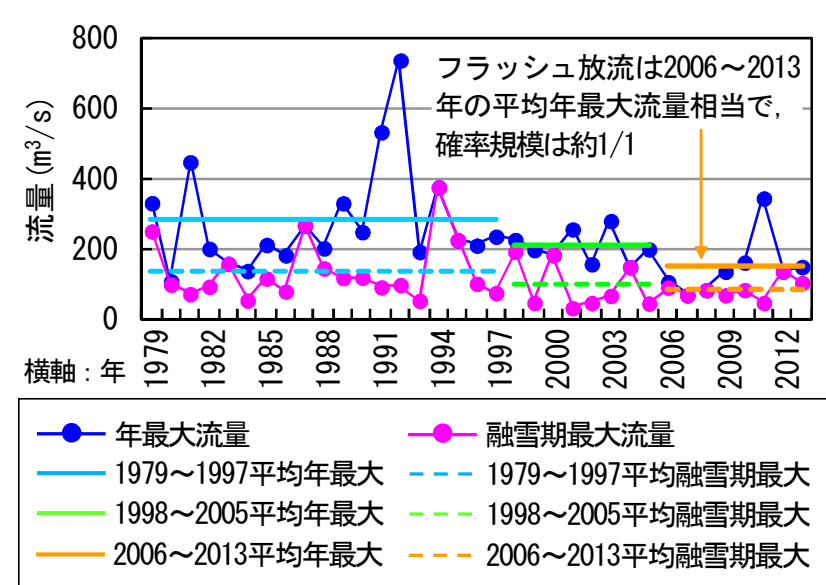

図-3 年最大 - 融雪期最大流量の変遷(上札内橋観測所)

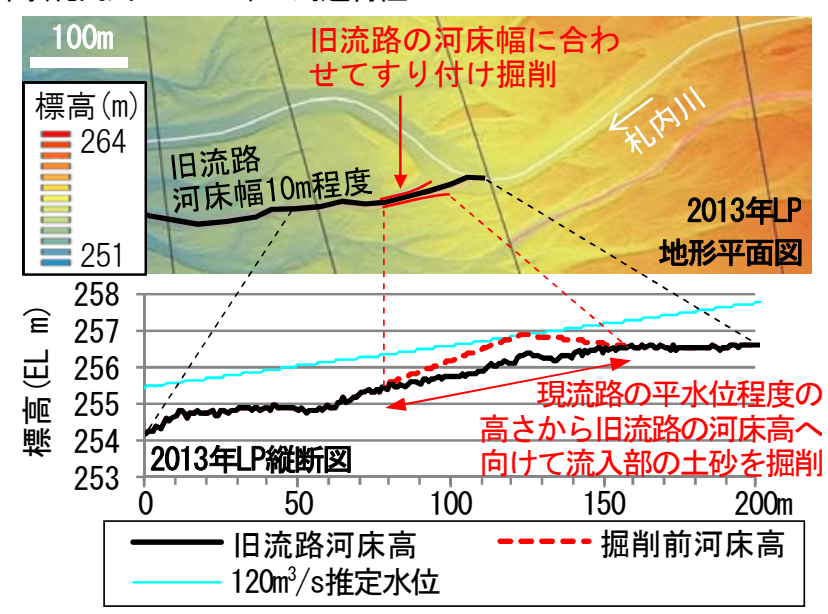

図-4Ｅエ区を例にしたエ区の標準掘削イメージ 

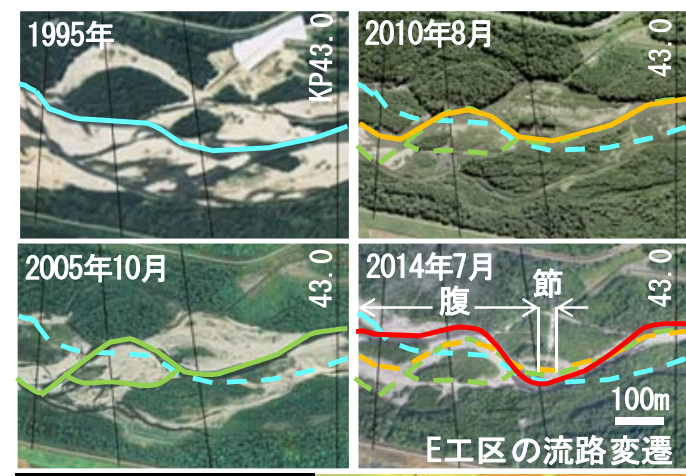

\section{3年LP地形平面図}

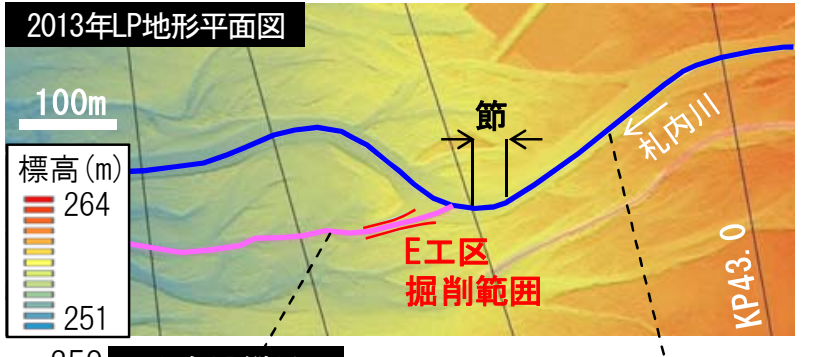

259 2013年LP絴断図

Е 258

Ш 257

紫 256

255

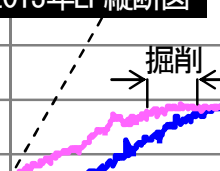

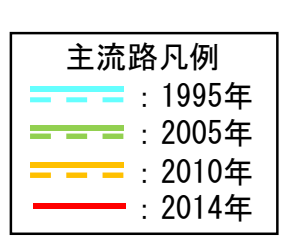

$00 \mathrm{~m}$

EI区の流路变畺
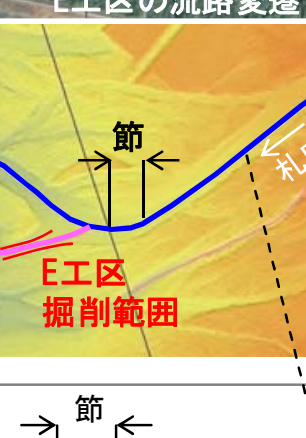
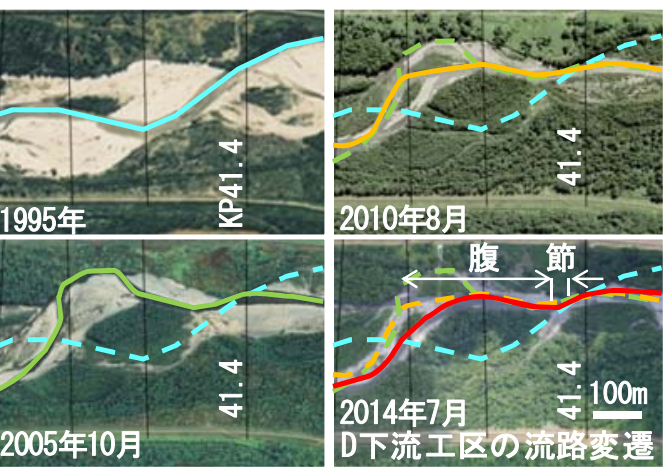

2010年8月

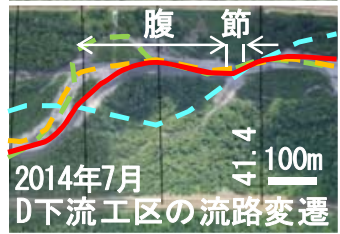

2013年LP地形平面図

$\begin{array}{lllllll}0 & 50 & 100 & 150 & 200 & 250 & 300(\mathrm{~m})\end{array}$
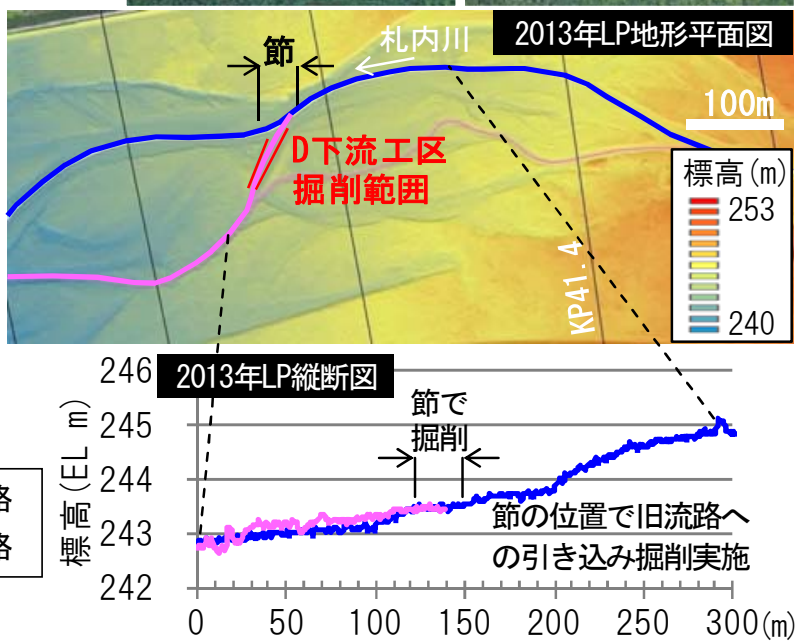

図-5 流路変動が発生した $\mathrm{E}$ 工 (左) と旧流路への流入が緩やかなD下流工区 (右) の流路変遷と平面・縱断形

\section{3．フラッシュ放流による旧流路維持効果の検証}

2011年出水による変化状況3)から，大規模な河道摚乱 には, 出水が生じる際に旧流路が維持されていることが 必要と考えられる.このため, 旧流路引き込み掘削後の 維持管理におけるフラッシュ放流の効果について，iRIC Nays2D 4.28)を用いた河床変動計算により検討を行った.

\section{（1）フラッシュ放流による河床変動状況の再現計算}

予測計算の実施にあたり，2013年のフラッシュ放流前 後の河床変動を再現し, 放流前後に測定されたLPデー タとの比較により再現性の確認を行った. 計算条件の一 覧を表-1に，計算に用いた流量八イドロを図-6に示寸. 河床材料の粒径は均一粒径とし，KP41，42，43におけ る2012年の60\%粒径の調查結果である59.2mm, 70.9mm, 112.4mmの3ケースを設定した. 3ケースの計算では，粒 径59.2mm とした場合の再現性が最も高い結果となった.

図-7に，河床材料の粒径を59.2mm とした場合のフ ラッシュ放流前後での河床変動量図を示す.この結果を 見ると，図-7の1の区域は実際より大きく侵食され，2の 区域は実際と異なり堆積傾向となった。 これは, 引き込 み掘削により流入するようになった旧流路では掃流力が 増加して1の区域で侵食が進行し, 引き込み前の主流路 は掃流力が低下して2の区域で堆積傾向になったものと 考えられる.このように，計算結果は実測值を完全には
表-1 河床変動計算（iRIC Nays2D 4.2）の条件

\begin{tabular}{|c|c|}
\hline 項目 & 設定条件 \\
\hline 流量（図-6） & 2013年フラッシュ放流実績ハイドロ \\
\hline 地形 & 2013年6月フラッシュ放流前計測LP \\
\hline 計算格子サイズ & $\begin{array}{l}5 \mathrm{~m} \times 5 \mathrm{~m} \text { （旧流路横断方向に1メッ } \\
\text { シュ以上入るサイス） }\end{array}$ \\
\hline 計算区間 & 札内川|KP41～43区間 \\
\hline 樹木生育範囲 & 2013年6月航空写真を判読して設定 \\
\hline 樹木の抵抗係数 & 0.07 \\
\hline 河床材料の粒径 & $\begin{array}{l}\text { KP41, 42, 43での2012年調査結果(d60) } \\
\text { から次の均一粒径を設定 } \\
\text { 59.2mm, 70.9mm, 112.4mm } \\
\text { ）再現検証の結果59.2mmを採用 }\end{array}$ \\
\hline $\begin{array}{l}\text { マニングの粗度 } \\
\text { 係数 }\end{array}$ & $\begin{array}{l}\text { 河床材料粒径からManning-Stricklerの } \\
\text { 式により算出 }\end{array}$ \\
\hline 流砂量式 & 芦田-道上式 \\
\hline
\end{tabular}

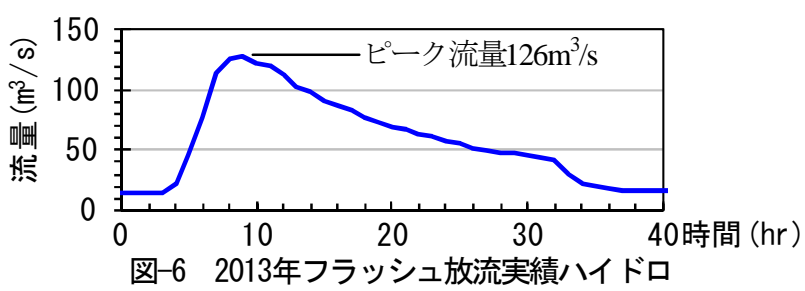

再現していないものの，水衝部における侵食傾向及びそ の近傍で見られる堆積の傾向は概ね再現されている. 河 床幅10m程度の旧流路についても, 河床変動規模は小さ いものの, $\mathrm{N} \sim Q 及 ひ ゙ ~ \mathrm{j} \sim \mathrm{k}$ の区域は, 侵食と堆積の傾向 が概ね再現されていることが確認される. 本検討では粒 径59.2mmを採用して予測計算を行う. 


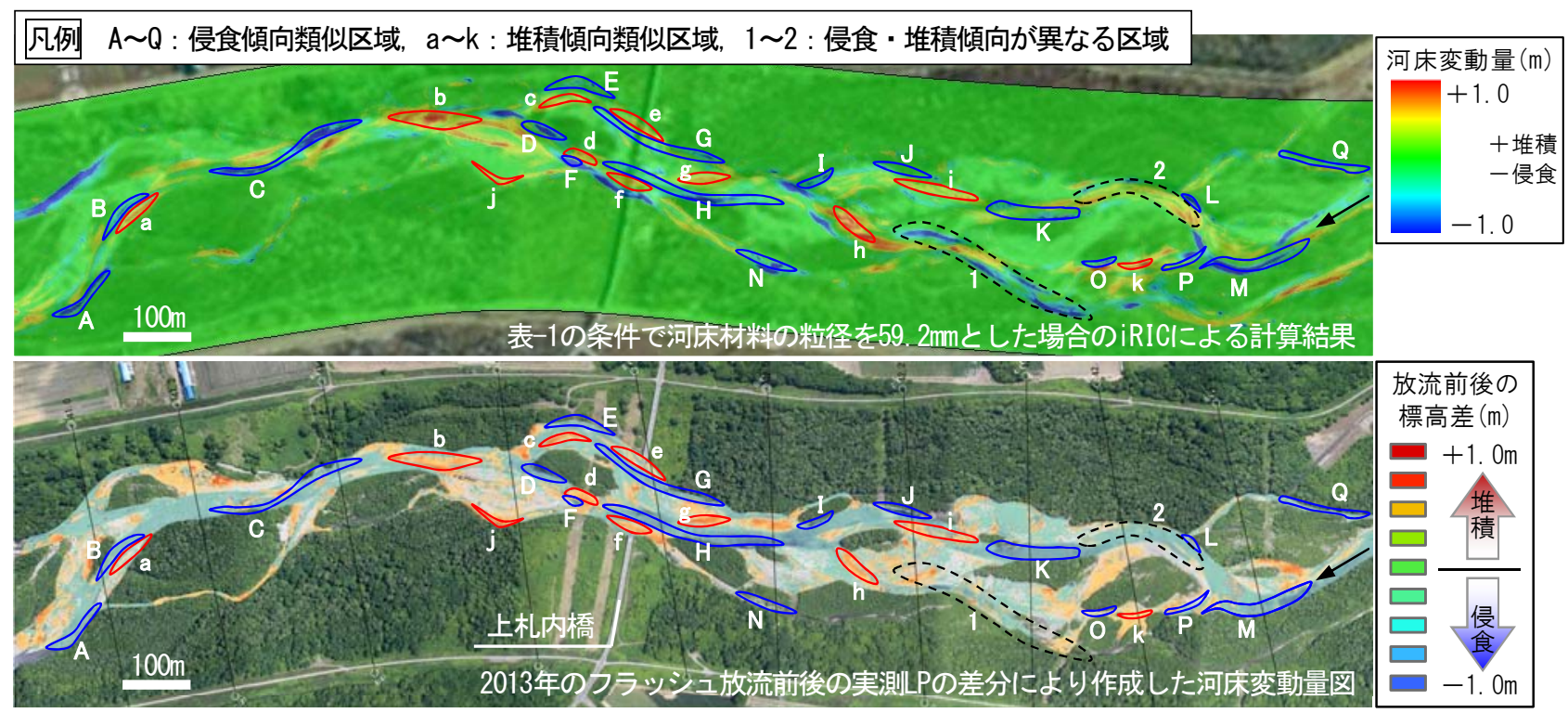

図-7＼cjkstart河床変動計算結果と実測LPI基づく河床変動量図との比較による再現検証結果

\section{（2）フラッシュ放流による旧流路維持の予測}

予測計算は，旧流路引き込み掘削後の地形で，流量条 件をフラッシュ放流実施の有無のみ变更して実施した. それぞれの流量条件を図-8 (a) 及び図-8 (b) に示寸．旧流 路内における河床変動の予測にあたり，旧流路の河床幅 が10m程度と狭いことを考慮し, 旧流路内を横断方向に 5メッシュ程度で分割することとし，計算格子サイズは $2 \mathrm{~m} \times 2 \mathrm{~m}$ とした．ただし，格子の微細化により計算時間 上の問題が生じたため, 計算区間をKP42〜43と短くし た。流量, 計算の格子サイズ及び区間以外の条件は表-1 と同じとした．E工区の引き込み掘削直後の河床䋡断図 と流量毎の推定無次元掃流力 $\tau_{*}$ を図-9に示寸． $\tau_{*}$ 算出の ための河川水位とエネルギー勾配は計算值，河床材料の 代表粒径は再現性の最も良かった59.2mmを用いた。こ

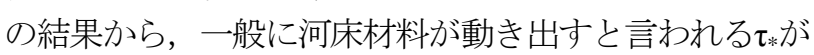
0.05 以上となる流量条件は, 引き込久掘削箇所は $120 \mathrm{~m}^{3} / \mathrm{s}$ 程度, その下流の旧流路では $80 \mathrm{~m}^{3} / \mathrm{s}$ 程度と推定された。

フラッシュ放流を実施しないケースでは，図-10 (a) 及 び図-11 (a)に示されるように, 旧流路流入部は維持され たものの, 旧流路内は堆積傾向を示した. これに対し, 放流を実施したケースは，図-10 (b) 及び図-11 (b) に示さ れるように，旧流路の流入部とその下流側が侵食され， 旧流路一の流入が明瞭な複列流路が形成された。融雪出 水は流量の緩やかな減少の過程で低流速・低水深となっ た区域において土砂堆積が生じやすく, 融雪出水に比心゙ ピーク流量が大きく流量の増減が鋭敏なフラッシュ放流 は, 短時間の河床変動により旧流路では堆積量より侵食 量の方が大きくなり旧流路が維持されたと考えられる.

また，単列流路の場合と比べて旧流路への分岐により 掃流力が低下寸る主流路は堆積傾向となるため, 図-12 に示すKP41.7付近における実際の地形の時系列変化に見 られるように, 河道内の比高差が縮小し, 交番現象皇が 生じやすい複列流路を形成する効果も期待できる.

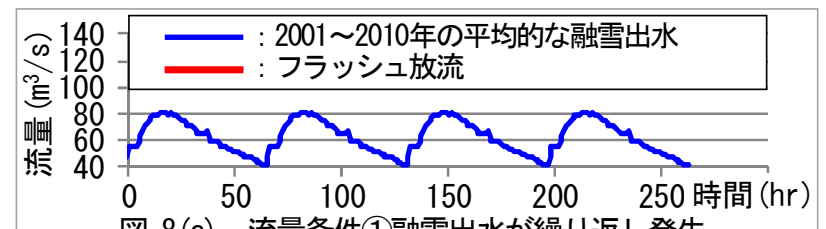

図-8 (a) 流量条件 (1)融雪出水が繰り返し発生

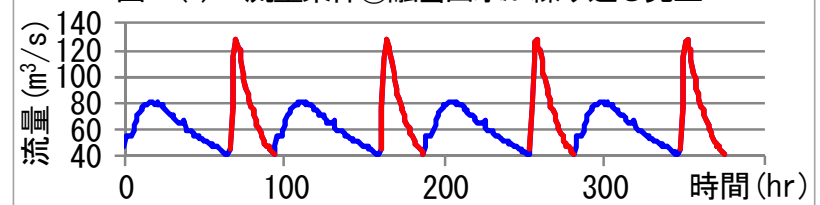

図-8（b） 流量条件(2)融雪出水と放流が繰り返し発生

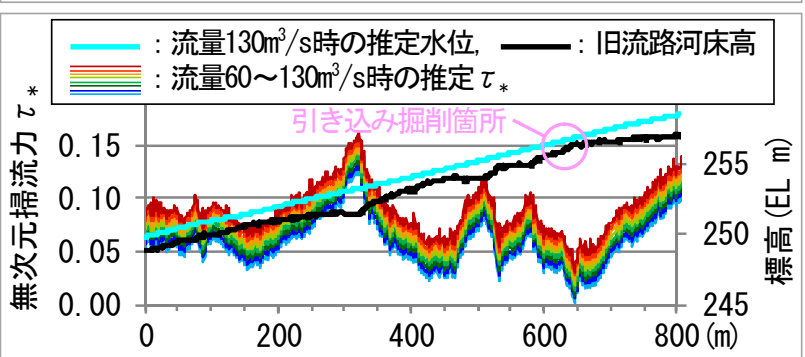

図-9 E工区旧流路の推定無次元掃流力維断図

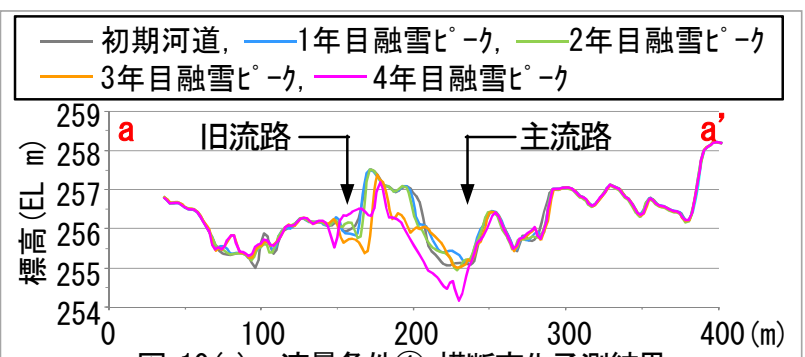

図-10 (a) 流量条件(1) 横断変化予測結果

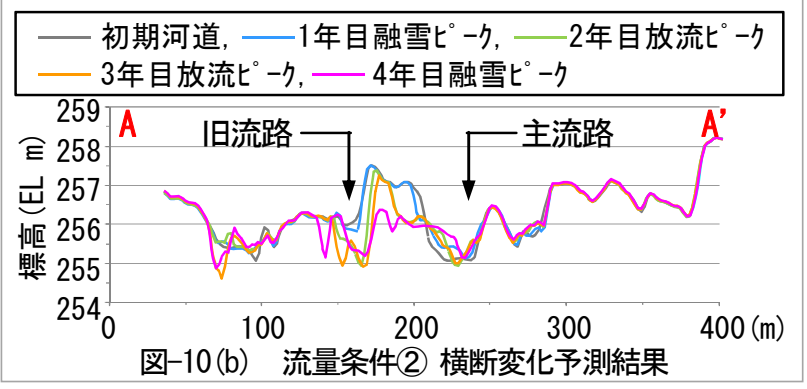



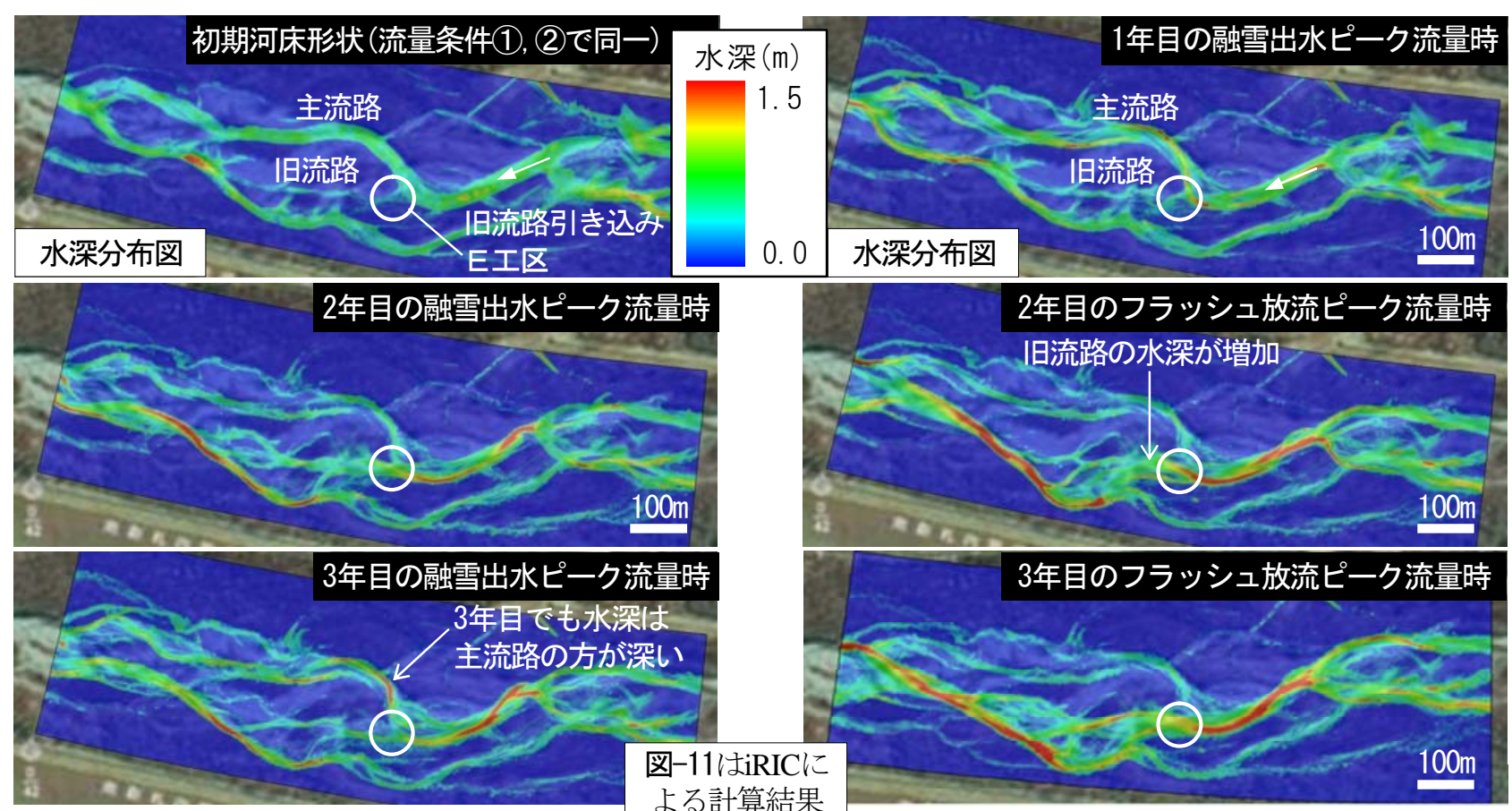

流量時

3年目のフラッシュ放流ピーク流量時

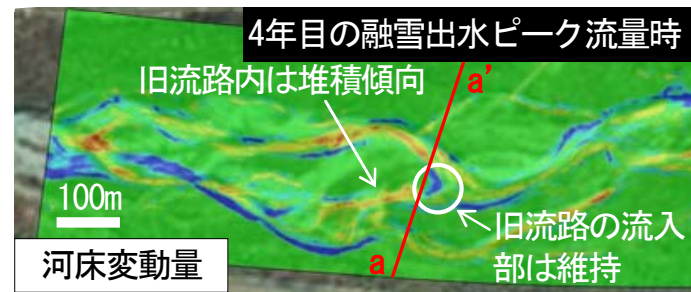

図-11はiRICに よる計算結果

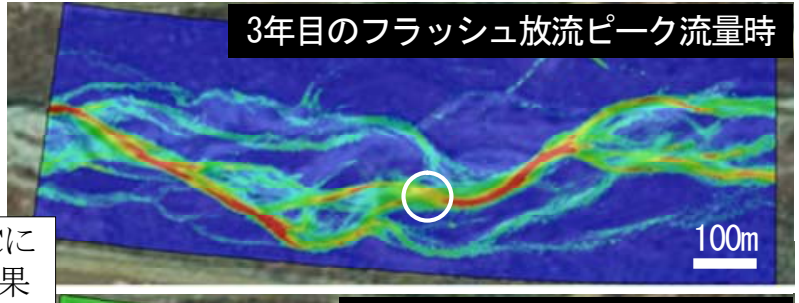
河床変動量 $(\mathrm{m})$

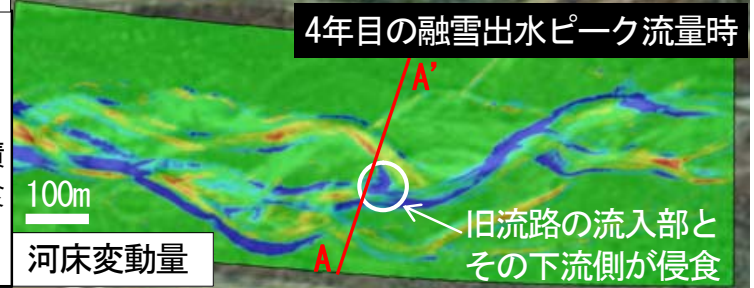

図-11(a) 流量条件1 水深分布 ·河床変動量予測結果

図-11(b) 流量条件(2) 水深分布・河床変動量予測結果
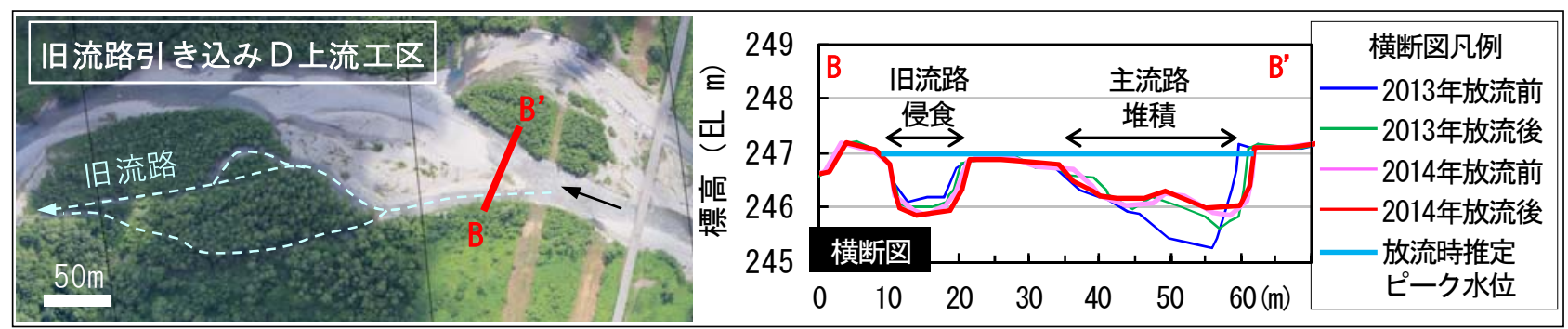

図-12＼cjkstart旧流路引き込み掘削後のフラッシュ放流による河道内の比高差縮小事例（放流前後の横断測量結果）

（3）旧流路維持により期待される効果の予測

フラッシュ放流による旧流路の維持が，大規模出水時 における河道擋乱に与える効果を把握するため, 旧流路 流入部が閉塞した河道（地形条件(1)）と旧流路引き込み 掘削後河道（地形条件(2)）の流路変動状況の違いを予測 した.この予測計算の流量は，図-13に示寸確率規模約 1/20の2011年出水実績ハイドロを用いた．流量と旧流路 流入部の地形条件以外の条件は表-1と同じとした.

旧流路流入部が閉塞したケースの河床変動範囲は，図 -14 (a) に示されるように限定的であった. これに対し, 旧流路引き込み掘削により複列流路を形成したケースで は，図-14(b)に示されるように，主流路沿いに加えて， E工区下流側の旧流路沿いでも大規模な侵食が発生し, 下流右岸方向一流路変動している．また，水衝部にあた るE工区掘削箇所が河岸侵食を伴って左岸上流側に移動 するなど，大きな流路変動も見られた．

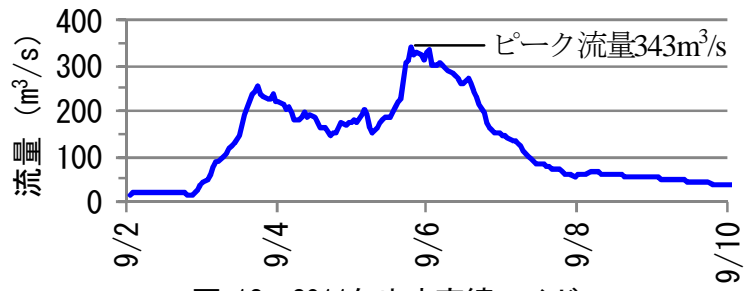

図-13２011年出水実績ハイドロ

2014年8月に発生した確率規模約1/3（ピーク流量約 $200 \mathrm{~m}^{3} / \mathrm{s}$, 暫定值）の出水前後の航空写真を比較したと ころ, 図-15に示されるように, E工区では実際の出水に おいても旧流路流入部左岸側とその下流側の旧流路沿い を侵食して下流右岸方向一流路変動する図-14 (b) と類似 した流路変動が確認された。

これらの結果は, フラッシュ放流による旧流路の維持 が出水時の流路変動の促進に効果的であることを示唆し ている. 


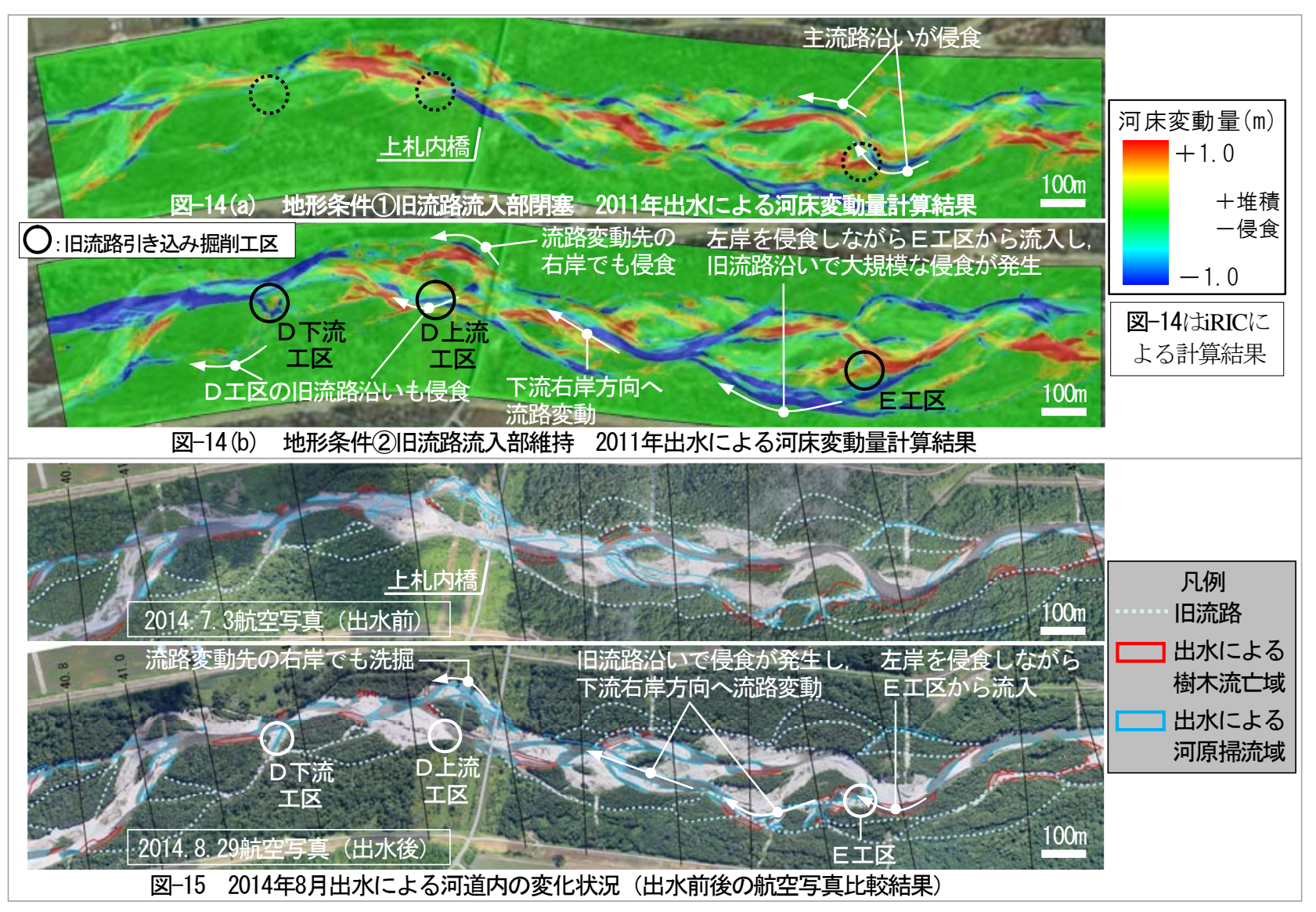

\section{4. おわりに}

本検討により次のことが示された.

・節腹連続河道では，節と淵，腹と瀬が対応寸る．旧流 路の分布と節・腹の位置を既往航空写真により確認し, 節上下流区間の河床縦断形の詳細調查により縦断的な 瀬・淵特性を把握した上で, 節直下流の瀬頭の位置で 旧流路へ引き込むことが複列流路回復のための調查及 び工事の効率化に資することが示された。

・札内川において碩河原の再生を目的として実施してい るフラッシュ放流は，引き込み掘削により回復を図っ た旧流路の維持及び河道内の比高差縮小の効果がある。 これにより，交番現象泉が生じや寸い複列流路を形成 する効果が期待される.

・旧流路の維持は, 出水時の流路変動の促進に効果的で あることが示唆された．樹木流亡を伴う流路変動の発 生を促すことにより，碩河原の再生が期待される.

謝辞 : 札内川の礫河原再生は，『札内川技術検討会』の 委員をはじめ多くの方々からの助言や協力を得て取り組 みが進められている．また，国土交通省河川砂防技術研 究開発公募地域課題分野「河川景観ネットワークの連続 性と時空間変化（代表 : 中村太士）」及び科研費「節腹 連続河道の形成機構の解明（代表 : 渡邊康玄）」の助成 を受けて行われた。ここに感謝の意を記す。

\section{参考文献}

1) 高橋輝好, 法村賢一, 武田淳史 : 札内川における碩河原再生 の取り組みについて, 北海道開発局技術研究発表会, 2015.

2) 北海道開発局帯広開発建設部: 札内川技術検討会資料, http://www.ob.hkd.mlit.go.jp/hp/kakusyu/satsunai_kentoukai/

3) 山口里実, 渡邊康玄, 武田淳史, 住友慶三 : 流路の固定化が 進行した河道における効率的な旧流路回復手法に関する検討, 河川技術論文集，第21巻，pp.217-222，2015.

4) 清水義彦，岩見収二，石川陽介，佐藤文泰，磯田忠生，遠藤 武志 : 洪水摚乱の誘発を目的とした中州掘削工事の効果評価 とその考察，河川技術論文集，第14巻，pp.169-174， 2008.

5) 松田浩一, 須藤達美, 内堀寿美男，大島秀則，清水義彦，藤 堂正樹 : 固定化砂州での掘削路開削による洪水摚乱の誘発と 樹林化抑制刘策に関する研究（その2），河川技術論文集， 第17巻, pp.233-238, 2011.

6) 渡邊康玄，武田淳史，川岸秀敏，住友慶三 : 札内川人工放流 における派川復元手法の検討, 応用生態工学会第18回研究発 表講演集, pp.275-278, 2014.

7) 渡邊康玄，長谷川和義，吉川泰弘，早川博 : 節腹連続河道の 形成に関寸る線形安定解析，土木学会論文集B1（水工学） Vol.70, No.4，I_991-I_996, 2014.

8) http://i-ric.org/ja/

9) 長谷川和義, 広瀬健治, 目黒嗣樹 : 山地河川における分岐部 流路交番現象に関する抽出実験とその解析，水工学論文集， 第47巻, pp.679-684, 2003.

(2015. 9. 30受付) 